\title{
The Assertive Mother in Toni Morrison's Sula
}

\author{
Miss. Dhavaleswarapu Ratna Hasanthi, M.A, M.Phil \\ Research Scholar (Ph. D), Dept. of English, Andhra University, Visakhapatnam \\ hasanthidr11@gmailcom
}

\begin{abstract}
The gender of an individual is an inescapable social reality, whereas genotypic sex is a biological reality, and there is no escape from experiencing both. Gender roles are stereotyped in societies based on the cultural influences prevalent in those societies. Moreover, gender roles are in a constant state of flux based on context and time. The propensity with which, black women are forced to take upon the three fold oppression catalyzed by gender, makes motherhood quiet a demanding affair for them. Toni Morrison's Sula published in 1973, is a novel about motherhood and sisterhood, and the nurturing bonds between women. This paper analyses gender with a black feminist perspective concentrating on the various facets of motherhood, displayed by the assertive mother figure Eva, in the novel Sula. Eva plays the roles of life giver, nurturer, protector, dictator, and a compassionate destroyer to the fullest, unparalleled by any other woman character in the novel. She stands out as a role model for women's strength and forbearance. Eva exists as an intriguing, unconventional, yet assertive mother in a free maternal space, loving and caring for Hannah, Plum, Sula and many other motherless children.
\end{abstract}

Keywords: Gender, Gender roles, Motherhood, Black feminism, Assertive mother

The gender of an individual is an inescapable social reality, whereas genotypic sex is a biological reality, and there is no escape from experiencing both. Culture determines to what extent, certain activities and roles are reserved for a gender. Gender roles are stereotyped in societies based on the cultural influences prevalent in those societies. Moreover, gender roles are in a constant state of flux based on, context and time. Rose M. Brewer in her article "Theorizing Race Class and Gender: The New Scholarship of Black Feminist Intellectuals and Black Women's Labour" has precisely summed up the influence of gender roles thrust on black womanhood by stating that: "Social constructions of black womanhood and manhood are inextricably linked to racial hierarchy, meaning systems and institutionalization. Indeed gender takes on meaning and is embedded institutionally in the context of the racial and class order: productive and social reproductive relations of the economy" (17). Toni Morrison's 1973 novel Sula depicts the aforesaid struggle of black women.

The propensity, with which black women are forced to take upon the three fold oppression catalyzed by gender, makes motherhood quiet a demanding affair. Along with the variables of racism, sexism and classism, the burdensome legacy of slavery, too has influenced the black family, and the role played by black women as mothers in the family. Black women had to work on the fields and homes of their masters, and their own homes too, managing both the public and private spheres of their life. Multi-tasking various activities, they have been the fulcrum of black families down generations. African-American women much to their dismay have been stereotyped as mammies, matriarchs, welfare recipients, and hot mommas, which reflects their oppression in the United States. As pointed out by Patricia Hills Collins "Challenging these controlling images has long been a core theme in Black feminist thought" (69). African American writers like Toni Morrison, Alice Walker, Gloria Naylor, Gayl Jones, and Paule Marshall to name a few, have tried to demystify the stereotyped images of black women, in dominant discourses. They have tried to capture and showcase the true images of black women in their works. Furthermore, they have tried to revitalize black motherhood through their fiction, and have echoed the thought that: "African-American women need a revitalized Black feminist analysis of motherhood that debunks the image of "happy slave," whether the White-malecreated "matriarch" or the Black-male-perpetuated "super strong Black mother" (Collins 176).

Motherhood being a very demanding role, affects the life of women, their behaviour and life choices as women, wives, and individuals. It is not an easy job to be an assertive mother figure crossing over the disparaging difficulties thrust on to their lives. Moreover, black motherhood is not uniform. 
"Black motherhood as an institution shows comparable diversity.... [it] is both dynamic and dialectical" (Collins 176). Some women consider motherhood as the foundation for selfenfranchisement and self-reliance, while others consider it to be a sure route to oppression and exploitation. "In contrast, motherhood can serve as a site where Black women express and learn the power of self-definition, the importance of valuing and respecting ourselves [themselves], the necessity of self-reliance and independence, and a belief in Black women's empowerment" (Collins 176). As purported by Davies, Morrison's novels "problematize the mother rather than romanticize her" (145). Morrison does not sentimentalize or idealize mothers in her novels, but rather shows them as normal women with metiers, fortes and foibles. She shows motherhood as a rich, empowering experience that steers women to self-reliance and empowerment.

Toni Morrison's Sula published in 1973, is a novel about motherhood and sisterhood, and the nurturing bonds between women. The novel revolves around the women characters in the novel, concentrating on the matriarchal line of three generations of women in two different families. It showcases the friendship between Sula and Nel, and further highlights how the mothering experienced by them and their predecessors, influences their life and the choices they make. Morrison through the novel challenges stereotyped black womanhood and motherhood. The maternal role played by black women is one marked by utmost responsibility, resistance and buoyancy. Toni Morrison in her novels, has created mother figures who are strong, fiercely independent, determined and violent for the best interests of their children. The novel presents how motherhood influences the life of the female characters, their families and the black community at large. Eva, Hannah, Sula, Helene and Nel are all influenced by their mothers and their personalities are an outcome of the maternal care or neglect experienced by them, as children. This paper, analyses gender with a black feminist perspective concentrating on the various facets of motherhood, displayed by the assertive mother figure Eva, in the novel Sula.

Critics like Gillespie and Kubitschek have eulogized Morrison's Sula, as it renders "a view of the development of the black female self through the mother-daughter relationship and through the selfin-community dynamic" (21-48). Motherhood to black women, is certainly a site of liberation, as they empower themselves in the act of preserving the lives of their children. Forerunner of modern motherhood studies, Andrea O'Reilly, has rightly said that the main core of black motherhood lies both in the practice and contemplation on "how to preserve, protect, and more generally empower black children so that they may resist racist practices that seek to harm them and grow into adulthood whole and complete" (O'Reilly 4). Motherhood observed here need not necessarily be biological, it can be in the form of communal mother work. African American history has been a witness to the proficiency of "othermothers" (O'Reilly 5), and their foster mothering. Both biological motherhood and foster motherhood are certainly sites of accountability and deliverance for black women. Morrison commenting on the stance of black women regarding raising children has rightly stated that "Our history as Black women is the history of women who could build a house and have some children and there was no problem...It is not a question, it's not a conflict. You don't have to give up anything. You choose your responsibilities" (Qtd in O'Reilly 20).

Marginality faced by black women makes motherhood a prospect leading to autonomy and resistance, rather than imprisonment. Regarding this stance, Hooks has succinctly stated that "marginality [can be seen] . . . more than a site of deprivation . . . it is also the site of radical possibility, a space of resistance ... a site one stays in, clings to even, because it nourishes one's capacity to resist" (150). Notable feminist philosopher, Sara Ruddick in Maternal thinking: Towards a Politics of Peace has coined the term "preservative love" (19) to describe the maternal instinct of a black woman. Moreover, in a depreciating atmosphere, despite the rigorous endeavours of black women "securing food and shelter, struggling to build and sustain safe neighbourhoods is what defines both the meaning and experience of black women's mother work" (O'Reilly 32). Sula set during the unnerving post-world war suffering, adversity and depressive state of affairs shows the preservative love of mothers for their children. The black mothers showcased in the novel are in a free maternal space, protecting the interests of their children. The care showered by the mother characters in the novel, is neither colossal nor uniform. The mothering showered or experienced by them, shapes the narrative and the lives of the characters in the novel. They are not just mothers but are also individuals who chart their own destiny because of the mothering or motherhood experienced by them. Morrison through the novel consciously breaks away from the stereotyped labelling ascribed to black motherhood. Nevertheless, she shows it as a site of emancipation and empowerment. 
The three generations of women in the Peace family Eva, Hannah and Sula have different maternal and mothering experiences when compared to the Wright women Rochelle, Helene and Nel showcased in the novel. This paper concentrates on the women in the Peace household alone to analyse the assertive mother character Eva. Moreover, the Peace women share more love and closeness in mother child relations, than the wright women. The men in the family are men for namesake, and do nothing significant for their women in handling the family. Neither Eva's Husband Boy Boy nor Hannah's husband Rekus take responsibility of the family. The women are left to fend for themselves and their children. After having seen the lives of Eva and Hannah, Sula understands that men are not that important in life than for pleasure, and decides not to beget children.

Eva's husband Boy Boy, leaves his young wife and children mercilessly to fend for themselves after five years of marriage. Moreover, Eva is wrecked by the troubled marriage that does no good to her. "After five years of a sad and disgruntled marriage BoyBoy took off. During the time they were together he was very much preoccupied with other women and not home much. He did whatever he could that he liked, and he liked womanizing best, drinking second, and abusing Eva third" (Morrison 32). When Boy Boy leaves her with three children, two daughters and a son, she has : " $\$ 1.65$, five eggs, three beets and no idea of what or how to feel. The children needed her; she needed money, and needed to get on with her life. But the demands of feeding her three children were so acute she had to postpone her anger for two years until she had both the time and the energy for it" (Morrison 32). Eva only thinks of providing the basic amenities for her children, with utmost love. She for a while banks on the help offered by her neighbours, the Suggs and Mrs Jackson, but understands that she cannot bank upon them forever as "winters were hard and her neighbours were not that much better off" (Morrison 32). Eva throughout her life faces the "asymmetrical organization of parenting" (Chowdorow 208) being the sole bread winner throughout her life not only for her children, but even her grandchild and many other waifs, without any complaint.

Eva does all that she needs to comfort her children, regardless of the inconvenience faced by her. For instance, when Plum shrieks and cries in pain as a child, Eva eases it at the expense of her inconvenience with "her shins and teeth freezing," while "her nostrils assailed" (Morrison 34). The inconvenience faced by her is best explained in the lines:

Deep in its darkness and freezing stench she squatted down, turned the baby over on her knees, exposed his buttocks and had shoved the last bit of food she had in the world ... up his ass. Softening the insertion with the dab of lard, she probed with her middle finger to loosen his bowels. Her fingernail snagged what felt like a pebble; she pulled it out and others followed. (Morrison 34)

Eva as a mother tries to lessen the pain and suffering of Plum, not just in his childhood but even in his adulthood. She bears Plum's whims, fancies, drug addiction and nonchalance as an adult. Eva's second daughter Pearl moves away from her at a very young age, and never cares for her. Hannah, Eva's eldest child, and her daughter Sula, depend on her throughout their lives. Eva looks after Sula and later on sponsors her education. Poverty or adverse conditions of any sort never dissuade or stop her from caring for her children.

Eva as a mother has a pragmatic outlook towards her life and that of her children. Eva takes up an unconventional manner, to end the financial woes in her family, which needs utmost courage. She leaves her children with Mrs Suggs for a day and returns after eighteen months, with one leg missing and a stash of cash to every one's surprise. The missing leg guarantees a monthly pension for her and her children. As soon as Eva comes to Bottom : "First she reclaimed her children, next she gave the surprised Mrs Suggs a ten-dollar bill, later she started building a house on Carpenter's Road, sixty feet from Boy Boy's one-room cabin, which she rented out (Morrison 34-35). The aforementioned lines show her maternal love. It has to be unquestionably acknowledged that "Eva's motherlove has taken on a double-edged destructiveness: it drives her to sacrifice herself in order to maintain her children economically, and in doing so absents her from them so that their love for her is diminished" (De Lancey 17).

Eva is not the conventional good saint like mother figure, but is a rather unconventional, assertive mother who cares utmost, for her children. Unlike Boy Boy, Eva does not abandon her children in search of pleasure. Like a mule, she bears the burden of the family single-handedly. There is no doubt that she seeks her happiness, but she equally cares for her children, at times evading her own comfort. 
Her children are her foremost priority. Morrison through the character of Eva has challenged the preordained classification of black women, more so black mothers, into good and bad. Eva seeks autonomy not just economically, but even sexually and she bequeaths this, to her lineage of women. She proclaims her sexuality and the other Peace women learn the same form her. "With the exception of BoyBoy, those Peace women loved all men. It was manlove that Eva bequeathed to her daughters. The Peace women simply loved maleness, for its own sake" (Morrison 41). Loving men is not a deterrent to Eva's motherhood. Eva is a tenacious mother character with her own flaws and foibles. O'Reilly commenting on Eva's character has said that, "Eva in particular distresses readers because the maternal power she claims upsets the comfortable notions of maternal powerlessness" (147). Eva conflates every conformity, and emerges as an ascendant woman. Yet, Eva does not fit within the bounds of a conventional, stereotyped, sexually lascivious woman who exists in a confined space. Diane Gillespie and Missy Dehn Kubitschek have eulogised the character of Eva stating that, "Of the three Peace Women, Eva has the most capacity for authenticity in caretaking. The extremity of her early life as a caregiver forced her to recognize her own as well as others' needs. She neither leaves the community permanently nor compromises herself in her relation with others" (38). The aforesaid lines reflect Eva's integrity as a humane, human being and mother.

Eva not only preserves her family with the money she has, but mothers many waifs and homeless children selflessly. The three Deweys and Tar Baby she mothers are an instance of the role played by her as an "othermother" (O'Reilly 5). Gillespie and Kubitschek commenting on this characteristic of Eva's character have said that "Eva's efforts extend from her immediate family to the larger community...Eva's house becomes a kind of extended family when she takes on the matriarchal role... Eva takes in homeless waifs...she becomes a connective force in the community, her traditional goodness a generative force for those around her" (35). These descriptions delegate Eva to an empowered maternal figure, having a social responsibility towards the black community. Therefore, it can be inferred that Eva exists in a free maternal space working for the welfare of not only her family, but even the black community as an assertive mother.

Eva's act of killing her son Plum does not kill the fondness of the readers for her, though this act challenges the dominant ideology of motherhood. She kills and frees Plum, as she cannot free him from his heroin addiction. In his childhood, she has freed him form severe physical pain at the expense of her own discomfort. In his adulthood she frees him from his painful life, at the expense of the pain she has to undergo in killing her son. Eva preserves Plum in death, as she has to do the best for him, and cannot see him in pain. Eva tells Hannah with utmost grief that:

“After all that carryin' on, just gettin' him out and keepin' him alive, he wanted to crawl back in my womb and well. ... I ain't got the room no more even if he could do it. . . He was a man, girl, a big old growed-up man. . . . I done everything I could to make him leave me and go on and live and be a man but he wouldn't and I had to keep him out so I just thought of a way he could die like a man not all scrunched up inside my womb, but like a man." (Morrison 72)

Morrison describes Eva's act of dousing Plum in kerosene, in a ritualistic way, as if it were "Some kind of baptism, some kind of blessing" (Morrison 47). The ritualistic terms used by Morrison connote to Eva's maternal love. O'Reily has befittingly commented about Eva's maternal love by stating that "The images of ritual and renewal promise a rebirth from death. Eva kills Plum so that he may be reborn... When a child is in pain, the first desire and duty of the mother is to put an end to that child's suffering" (149). Eva can be viewed as a destroyer after the death of Plum, which is fallacious. In fact, death liberates Plum from his painful life. This act of Eva has to be seen as mercy killing or euthanasia, rather than foul murder.

Eva looks after her daughter Hannah throughout her life. She is both her emotional and financial anchor. The second generation of the Peace women is represented by Hannah, Eva's first child. Widowed when Sula is three, she spends life doing all that she wants to do, caring for Eva and Sula. She moves to Eva's home "prepared to take care of it and her mother forever" (Morrison 41). Like Eva, she too embraces her sexuality freely, but cannot be labelled as a stereotype. After the death of Rekus, her husband, she raises Sula with the help of her mother Eva. She resists categorization and confinement like Eva, as a woman and mother. Hannah refuses "to live without the attentions of a man and after Rekus' death had a steady sequence of lovers, mostly the husbands of her friends and neighbors" (Morrison 42). Hannah consciously seeks to make herself, and least cares about what 
others think about her. The biggest flaw in her personality is that she does not seek financial independence like Eva which sabotages her being as a woman, and this leads to self-doubt in every aspect of life. Hannah knows fully well that, Eva cares for her but has her own doubts about Eva's maternal love as does Sula later on, about hers. Hannah asks Eva: "Mamma, did you ever love us?" (Morrison 67). She thinks for a second and answers: "No. I don't reckon I did. Not the way you thinkin" (Morrison 67). This answer stuns Hannah. Eva admonishes Hannah and tells her:

"No time. They wasn't no time. Not none. Soon as I got one day done here came a night. With you all coughin' and watchin' so TB wouldn't take you off and if you was sleeping' quiet I thought, O Lord, they dead and put my hand over your mouth to feel if the breath was comin' what you talkin' 'bout did I love you girl I stayed alive for you, can't you get that through your thick head or what is that between your ears, heifer?" (Morrison 69)

In Eva's generation the main priority of mothers has been to look that their children are alive, are with them, and provide for their basic needs in an impoverished atmosphere that is terribly racist and sexist. Eva plays all the roles expected of her with equal aplomb and felicity as her utmost responsibility rather than an encumbrance.

Hannah takes Eva's boisterous nature as callousness, as she is not a strong individual or mother figure like Eva. Hannah unlike Eva is a dispassionate mother. Despite being a mother, Hannah fails to understand that "Love and anger can exist concurrently; anger at the conditions of motherhood can become translated into anger at the child, along with the fear that we are not 'loving'; grief at all we cannot do for our children in a society (Rich 52). Hannah hasn't faced squalid demeaning conditions faced by Eva, as Eva takes care of her and Sula. Moreover, Sula, her daughter, has no true love for her. This creates a conflict between her and Sula, and this distances them forever. She tells a friend of hers “. . . You love her, like I love Sula. I just don't like her. That's the difference” (Morrison 57). Hannah does not try to correct Sula's indifferences, as a responsible mother. Moreover, there is no great attachment between Hannah and Sula. When Hannah is dying on account of accidental fire, Eva comes to her rescue, but Sula watches her mother burn in fire indifferently. Eva sees "Sula standing on the back porch just looking" (Morrison 78) at Hannah burn in utmost pain. Hannah is the weakest image of Eva, as she is scared of Eva and her strong maternal image. The death of Hannah leaves an ineffaceable forfeiture in Eva's life. Despite all the limitations, Hannah exists as an unconventional mother caring for Sula, when alive. She dilutes her maternal instinct in the process of not being Eva, and turns out to be an unassertive mother.

Sula, Hannah's daughter and Eva's granddaughter is influenced by both her mother and grandmother. Eva is called as "Big Mamma" (Morrison 92) by Sula for being the unquestionable mother figure at home, with regard as well as awe. Sula is counter foil to Eva, as she is a free, careless woman, least caring for people around her. She feels ostracized when her mother Hannah says that she does not like her. She understands it as insouciance, and realizes that "there was no other ... [she] could count on" (Morrison 118-119). The personality of Sula is best described as one who: "lived out her days exploring her own thoughts and emotions, giving them full reign, feeling no obligation to please anybody unless their pleasure pleased her" (Morrison 118). Moreover, Sula hates emotional dependence and believes that love is a distant dream, and that the hunger of the body alone needs to be quenched. She gets involved with many men least caring for them or their families. She discards motherhood totally, as she finds it extremely demanding. When Eva asks her "When you gone to get married? You need to have some babies. It'll settle you" (Morrison 92). Sula defiantly answers: "I don't want to make somebody else. I want to make myself" (Morrison 92). Eva has seen how autonomous motherhood has made her, and she wants her granddaughter to embark on a journey of fulfilment and empowerment. She warns Sula "It ain't right for you to want to stay off by yourself. You need ... I'm a tell you what you need" (Morrison 92). Sula prefers not to listen to Eva, and this fashions her have "no centre, no speck around which to grow" (Morrison 119). This embarks her on a loveless, doomed life. It becomes impossible for Eva to stop the doom on Sula, yet she cares and looks after her as far as possible, as a loving mother figure till she is forcibly put in Sunnydale.

Eva acts as a dictator dictating the lives of her children, grandchild and reared children, only to protect them with the best of her intentions, from the denigrating, insolent circumstances they are exposed to. After having undergone, similar challenging and demanding circumstances, Hannah, and Sula understand the tripartite subjugation under which black women are forced to live. After becoming a mother, Hannah understands the nuances of motherhood, while Sula does not dare to take the route to 
motherhood. Eva is a free black mother, who embraces autonomy, sexuality and motherhood with equal aplomb, pride and fondness. Motherhood to her is a site of resistance, resilience, happiness, empowerment, emancipation and the greatest reason to live. Eva stands out as a role model for "womens capacities and nature." (Chodorow 208). Eva plays the roles of life giver, nurturer, protector, dictator, and a compassionate destroyer to the fullest, unparalleled by any other woman character in the novel. She exists as an intriguing, unconventional, yet assertive mother figure in a free maternal space, loving and caring for Hannah, Plum, Sula and many other motherless children.

\section{REFERENCES}

[1] Brewer, Rose M. "Theorizing Race Class and Gender: The New Scholarship of Black Feminist Intellectuals and Black Women's Labor." Theorizing Black Feminisms:The Visionary Pragmatism of Black Women. Ed. Stanlie M. James and Abena P.A. Busia. London and New York: Routledge, 1993, 13-30. Print.

[2] Chodorow, Nancy. The Reproduction of Mothering: Psychoanalysis and the Sociology of Gender. Berkeley: University of California Press, 1978. Print.

[3] Collins Patricia Hill. Black Feminist Thought: Knowledge Consciousness and the Politics o Empowerment.2nd ed. New York: Routledge, 2002. Print.

[4] Davies, Carol Boyce. Black Women Writing and Identity: Migrations of the Subject. New York and London: Routledge, 1994. Print.

[5] DeLancey, Dayle B. "Motherlove is a Killer: 'Sula' 'Beloved', and the Deadly Trinity of Motherlove.” SAGE: Scholarly Journal on Black Women 7.2 (1990): 15-18.Print.

[6] Gillespie, Diane and Missy Dehn Kubitschek. "Who Cares? Women-Centered Psychology in Sula." Black American Literature Forum 24: 1 (Spring 1990): 21- 48. Print.

[7] Hirsh, Marianne. "Maternal Narratives: Cruel Enough to Stop the Blood." Reading Black Reading Feminist: A Critical Anthology. Ed. Henry Louis Gates Jr. New York: Meridian, 1990. 415-30.Print.

[8] Hooks, Bell. Yearning: Race, Gender, and Cultural Politics. Boston: South End,1990. Print.

[9] Morrison, Toni. Sula. New York: Penguin, 1973. Print.

[10] O'Reilly, Andrea. Toni Morrison and Motherhood: A Politics of the Heart. Albany: State University of New York Press, 2004. Print.

[11] Rich, Adrienne. Of Woman Born-Motherhood as Experience and Institution. New York W.W. Norton \& Company, 1976. Print.

[12] Ruddick, Sara. Maternal Thinking: Toward a Politics of Peace. Boston: Beacon Press, 1989. Print.

\section{AUTHOR's BIOGRAPHY}

Miss. Dhavaleswarapu Ratna Hasanthi M.A, M.Phil., is a research scholar (Ph. D) from the Department of English, Andhra University, Visakhapatnam. She has cleared UGC NET and AP SET. A UGC JRF Awardee, Hasanthi, is doing her research on the novels of Alice Walker. She has a couple of research publications to her credit. 